\title{
TINGKAT KECEMASAN MASYARAKAT SAAT PENCABUTAN GIGI BERDASARKAN USIA, JENIS KELAMIN DAN ASAL DAERAH DENGAN SURVEI ONLINE
}

\author{
(DENTAL ANXIETY AMONG PEOPLE DURING TOOTH EXTRACTION BY AGE, \\ GENDER AND AREA OF ORIGIN WITH ONLINE SURVEY)
}

\author{
Hendry Rusdy, Beverly \\ Departemen Bedah Mulut dan Maksilofasial \\ Fakultas Kedokteran Gigi Universitas Sumatera Utara \\ Jl. Alumni No. 2, Kampus USU Medan 20155
}

\begin{abstract}
Anxiety is a subjective response in a harmless situation or an emotional problem which is caused by human themselves. Anxiety is a major contributor to the reluctance of people to get dental treatment. Dental anxiety was assessed by using Modified Dental Anxiety Scale (MDAS) that was remodified to match during tooth extraction and is widely spread in the internet. A total of 1298 responses were collected two months later. 11-20 years old age group is reported to be moderately anxious with a percentage of $43.51 \%$, while $21-40$ years old group and $41-65$ years old group were found to be not anxious or slightly anxious with a percentage of $47.04 \%$ and $62.65 \%$ respectively. A total of $45.42 \%$ female were found to be moderately anxious while $52.75 \%$ of male were not anxious or slightly anxious. $52.63 \%$ of people from Indonesia East Time Zone were reported to be moderately anxious, meanwhile people from Indonesia West Time Zone and Indonesia Central Time Zone were not anxious or slightly anxious with a percentage of 46.05 and $52.41 \%$ respectively. The prevalence of dental phobia among people was $4.63 \%$. In conclusion, dental anxiety were found higher in younger ages group, female and people from Indonesia East Time Zone.
\end{abstract}

Key words: dental anxiety, dental phobia, anxiety scale

\begin{abstract}
Abstrak
Kecemasan adalah respons subjektif seseorang bukan pada keadaan berbahaya atau masalah emosional yang penyebabnya adalah diri sendiri. Kecemasan adalah salah satu faktor besar dalam diri manusia yang mempengaruhi seseorang enggan mendapatkan pelayanan kesehatan gigi. Kecemasan dental diperoleh dengan menggunakan Modified Dental Anxiety Scale yangdimodifikasi sesuai dengan keadaan pencabutan gigi dan disebarkan melalui internet. Sejumlah 1298 responden diperoleh dua bulan kemudian. Kelompok usia 11-20 tahun dilaporkan cemas sedang dengan persentase $43,51 \%$, sedangkan kelompok usia 21-40 tahun dan 41-65 tahun dilaporkan tidak cemas atau cemas ringan dengan persentasemasing-masing $47,04 \%$ dan $62,65 \%$. Sejumlah $45,42 \%$ wanita dilaporkan cemas sedang sedangkan $52,75 \%$ laki-laki tidak cemas atau cemas ringan. Sejumlah $52,63 \%$ warga negara Indonesia bagian timur dilaporkan cemas sedang, sedangkan warga negara Indonesia bagian barat dan tengah dilaporkan tidak cemas atau sedikit cemas dengan persentase $46,05 \mathrm{dan} 52,41 \%$ masing-masing. Prevalensi fobia atau cemas parah pada masyarakat adalah 4,63\%. Sebagai kesimpulan, kecemasan dental ditemukan lebih tinggi pada kelompok usia yang lebih muda, perempuan dan warga negara Indonesia bagian timur.
\end{abstract}

Kata kunci: kecemasan dental, dental fobia, skala kecemasan

\section{PENDAHULUAN}

Kecemasan dental menduduki posisi kelima sebagai situasiyang paling sering ditakutkan. Prevalensi yang tinggi sering membuat pasien enggan atau menghindari kunjungan ke dokter gigi karena rasa cemas terhadap tindakan dental tersebut. Hanya sebagian kecil pasien menyatakan bahwa mereka tidak me- rasa cemas sama sekali ketika ditempatkan di lingkungan dental. ${ }^{1}$ Kecemasan adalah suatu bentuk emosional yang normal dialami manusia dari waktu ke waktu. Manusia merasa cemas ketika sedang gugup, menghadapi suatu persoalan baik pekerjaan, ujian maupun ketika dihadapkan untuk membuat suatu keputusan dan perasaan tertekan., ${ }^{2,3}$ Menurut Encyclopaedia Britannica, kecemasan tidak sama 
dengan ketakutan. Ketakutan terjadi ketika seseorang berada dalam keadaan yang berbahaya, misalnya pada saat keamanan seseorang terancam, sedangkan kecemasan adalah respons seseorang bukan pada keadaan yang berbahaya dan merupakan respons subjektif atau masalah emosional penyebabnya adalah diri sendiri. ${ }^{4}$

Ansietas atau kecemasan adalah salah satu faktor yang memiliki peran besar dalam diri manusia untuk enggan mendapatkan pelayanan kesehatan gigi. Hal yang dicemaskan masyarakat tentang tindakan dental adalah akan terjadinya rasa sakit, bengkak, tidak dapat berfungsinya fungsi stomatognatik, dan komplikasi akibat tindakan pelayanan kesehatan gigi. ${ }^{5}$

Berdasarkan penelitian yang dilakukan oleh Australia Research Centre for Population Oral Health menyatakan bahwa orang yang menghindari kunjungan ke dokter gigi memiliki tingkat kecemasan yang lebih tinggi dapat disebabkan karena rasa sakit, malu, tidak tahu apa yang akan dilakukan dokter gigi terhadap dirinya, suntikan dan biaya perawatan gigi. $^{6}$

Hasil penelitian Devapriya Appukuttan dkk. di India menunjukkan bahwa wanita lebih cemas daripada pria serta adanya hubungan dimana responden menunda kunjungan ke dokter gigi karena cemas. ${ }^{7}$ Hasil penelitian yang dilakukan oleh Adelina Rahmayani di RSGMP USU pada tahun 2014, Medan, Indonesia juga menunjukkan hasil yang sama dimana pria lebih banyak mengalami cemas ringan dan wanita lebih banyak mengalami cemas sedang. Berdasarkan kelompok usia, dewasa muda (18-33 tahun) lebih banyak mengalami cemas sedang sedangkan usia dewasa (34-49 tahun) serta lansia ( $>49$ tahun) lebih banyak mengalami cemas ringan. ${ }^{8}$

Penelitian yang dilakukan oleh Joyce Kandou dkk. di Manado menunjukkan bahwa 31 dari 47 responden merasa cemas rendah pada pencabutan gigi dimana sebagian dari mereka berjenis kelamin perempuan dan pasien dewasa muda (18-30 tahun) memiliki kecemasan sedang dibanding dengan pasien dewasa (31-65 tahun). ${ }^{9}$

Pengukuran tingkat kecemasan telah banyak dilakukan pada beberapa penelitian, baik melalui observasi langsung, kuisioner maupun dengan pengukuran tanda vital seperti nadi dan pernafasan yang pernah dilakukan oleh Adelina Rahmayani di RSGMP USU. ${ }^{8}$ Pada kesempatan ini, metode online mempunyai peluang untuk menjadi suatu alat survei dalam mengumpulkan data tingkat kecemasan karena pada tahun 2013, pengguna jasa internet di Indonesia mencapai 71,19 juta orang atau 28 persen dari total populasi yang berjumlah 248 juta orang, jumlah tersebut naik sekitar 13 persen dari 63 juta pengguna internet pada tahun sebelumnya menurut Asosiasi
Penyelenggara Jasa Internet Indonesia (APJII). ${ }^{10}$

\section{BAHAN DAN METODE}

Jenis penelitian ini adalah survei deskriptif. Penelitian dilakukan dalam waktu dua bulan (November 2014 sampai Januari 2015) dengan menyebarkan kuisioner melalui internet dengan memanfaatkan Google Form untuk membuat kuesioner, Google Sheet untuk menerima jawaban responden dan jejaring sosial untuk menyebarkan alamat URL kuesioner. Kategori usia menurut Mohammad adalah 11-20 tahun (pubertas), 21-40 tahun (dewasa), 41-65 tahun (setengah umur) dan diatas 65 tahun (lanjut usia). ${ }^{15}$ Kuesioner Modified Dental Anxiety Scale dilakukan sedikit modifikasi sehingga menyerupai keadaan saat pencabutan gigi dan terdiri atas 5 pertanyaan:

1. Anda akan mengunjungi dokter gigi esok hari dengan tujuan mencabut gigi. Bagaimana perasaan Anda?

2. Pada saat sedang menunggu di ruang tunggu praktik dokter gigi. Bagaimana perasaan Anda?

3. Pada saat akan dibius lokal sebelum pencabutan gigi. Bagaimana perasaan Anda?

4. Pada saat akan dilakukan pencabutan gigi. Bagaimana perasaan Anda?

5. Pada saat akan dilakukan penjahitan bekas luka pencabutan. Bagaimana perasaan Anda?

Setiap pertanyaan memiliki skor 1 sampai 5 sehingga skor akhir responden berkisar 5 sampai 25 . Nilai tersebut kemudian dikonversikan ke skala Corah's Dental Anxiety Scale menurut penelitian Freeman, dkk. $^{16}$

1. Skor 5-10: tidak cemas atau cemas rendah

2. Skor 11-16: cemas sedang

3. Skor 17-19: cemas tinggi

4. Skor 20-25: cemas parah (atau fobia)

Subjek penelitian berjumlah 1383 orang namun 85 di antaranya tidak dapat digunakan karena tidak sesuai dengan pernyataan sehingga jumlah responden adalah 1298.

\section{HASIL}

Hasil penelitian pada responden usia pubertas menunjukkan kecenderungan cemas sedang 43,51\%, sedangkan masyarakat pada usia dewasa dan usia setengah cenderung tidak cemas atau cemas rendah dengan persentase $47,04 \%$ dan $62,65 \%$.

Masyarakat pada usia lanjut ada empat responden, dua responden termasuk kategori tidak cemas atau cemas ringan dan yang lainnya berada pada kategori cemas sedangsehingga tidak dapat dibuat kesimpulan hasil penelitian untuk usia lanjut. 
Tabel 1. Karakteristik responden yang mengisi survei online $(\mathrm{n}=1298)$

\begin{tabular}{lccc}
\hline & Karakteristik responden & Jumlah & $\%$ \\
\hline Usia & $11-20$ (pubertas) & 416 & 32,05 \\
Tahun) & $21-40$ (dewasa) & 795 & 61,25 \\
& $41-65$ (setengah umur) & 83 & 6,39 \\
Jenis kelamin & $>65$ (lanjut usia) & 4 & 0,31 \\
& Laki-laki & 673 & 51,85 \\
Asal daerah & Perempuan & 625 & 48,15 \\
& Indonesia bagian barat (WIB) & 1077 & 82,97 \\
& Indonesia bagian tengah (WITA) & 145 & 11,17 \\
\hline
\end{tabular}

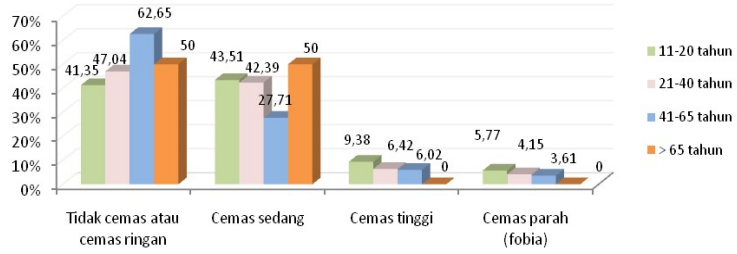

Gambar 1. Persentase tingkat kecemasan masyarakat saat pencabutan gigi berdasarkan usia

Responden laki-laki cenderung tidak cemas atau cemas ringan $(52,75 \%)$ sedangkan perempuan cenderung cemas sedang $(45,44 \%)$. Fobia juga terlihat lebih tinggi pada perempuan $(6,72 \%)$ daripada lakilaki $(2,67 \%)$

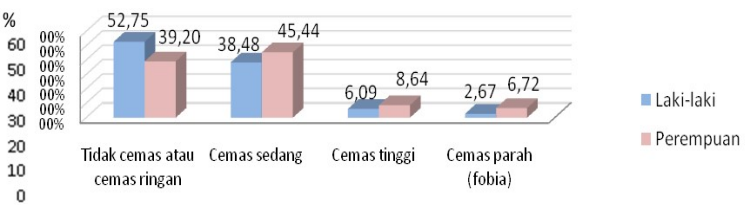

Gambar 2. Persentase tingkat kecemasan masyarakat saat pencabutan gigi berdasarkan jenis kelamin

Responden dari wilayah Indonesia bagian barat dan tengah cenderung tidak cemas atau cemas rendah $(46,05 \%$ dan $52,41 \%)$ sedangkan wilayah Indonesia bagian timur cenderung cemas sedang $(52,63$ $\%)$. Fobia juga tampak paling tinggi pada responden yang berasal dari Indonesia bagian timur yaitu $5,26 \%$.

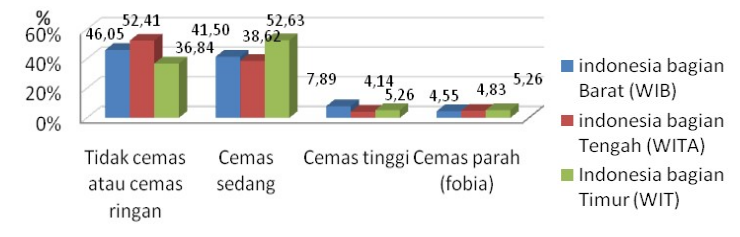

Gambar 3. Persentase tingkat kecemasan masyarakat saat pencabutan gigi berdasarkan asal daerah

Tingkat kecemasan masyarakat saat pencabutan gigi umumnya sedikit cemas pada usia 11-20 tahun dan 21-40 tahun. Namun untuk tindakan penjahitan bekas pencabutan, terjadi peningkatan kecemasan menjadi cemas (Tabel 7 dan Tabel 8). Pada kelompok usia yang lebih tua (41-65 tahun), responden tidak cemas pada waktu sehari sebelum pencabutan gigi dan menunggu di ruang tunggu. Peningkatan kecemasan menjadi sedikit cemas tampak dimulai dari pembiusan lokal, pencabutan gigi dan penjahitan bekas pencabutan (Tabel 9).

Untuk pencabutan gigi, persentase tidak cemas pada laki-laki lebih tinggi dibandingkan perempuan sebaliknya persentase cemas, sangat cemas dan sangat cemas sekali ditemukan perempuan lebih tinggi dibandingkan dengan laki-laki (Tabel 10).

Kecemasan responden berdasarkan asal daerah secara umum menunjukkan sedikit cemas dan cemas hanya pada saat penjahitan bekas pencabutan (Tabel 11, Tabel 12 dan Tabel 13), tetapi persentase responden dari Indonesia bagian tengah ketika menunggu di ruang tunggu menunjukkan tidak cemas 42,07 (Tabel 12) sedangkan responden dari Indonesia bagian barat dan timur menujukkan cemas. Pada masyarakat Indonesia bagian tengah, persentase tidak cemas lebih tinggi dibandingkan pada masyarakat di bagian timur dan barat. Persentase cemas yang tinggi adalah pada waktu pembiusan, pencabutan dan penjahitan bekas pencabutan gigi, baik pada masyarakat Indonesia bagian barat, tengah dan timur.

Tabel 7. Karakteristik persentase kecemasan saat pencabutan gigi kelompok usia 11-20 tahun

\begin{tabular}{lccccc}
\hline \multicolumn{1}{c}{ Aktivitas } & $\begin{array}{c}\text { Tidak } \\
\text { cemas } \\
(\%)\end{array}$ & $\begin{array}{c}\text { Sedikit } \\
\text { cemas } \\
(\%)\end{array}$ & $\begin{array}{c}\text { Cemas } \\
(\%)\end{array}$ & $\begin{array}{c}\text { Sangat } \\
\text { cemas } \\
(\%)\end{array}$ & $\begin{array}{c}\text { Sangat } \\
\text { cemas } \\
\text { sekali } \\
(\%)\end{array}$ \\
\hline Sehari sebelumpencabutan gigi & 32,21 & 51,44 & 11,78 & 2,64 & 1,92 \\
Menunggu di nuang tunggu & 35,10 & 43,03 & 14,42 & 4,81 & 2,64 \\
Akan dibius lokal & 24,04 & 38,46 & 21,88 & 9,13 & 6,49 \\
$\begin{array}{l}\text { Akan dilakukan pencabutan gigi } \\
\text { Akan dilakuka penjahitan bekas }\end{array}$ & 19,71 & 37,02 & 23,08 & 12,74 & 7,45 \\
pencabutan & 8,41 & 23,80 & 23,80 & 20,19 & 23,80 \\
\hline
\end{tabular}


Tabel 8. Karakteristik persentase kecemasan saat pencabutan gigi kelompok usia 21-40 tahun

\begin{tabular}{lccccc}
\hline \multicolumn{1}{c}{ Aktivitas } & $\begin{array}{c}\text { Tidak } \\
\text { cemas }(\%)\end{array}$ & $\begin{array}{c}\text { Sedikit } \\
\text { cemas }(\%)\end{array}$ & $\begin{array}{c}\text { Cemas } \\
(\%)\end{array}$ & $\begin{array}{c}\text { Sangat } \\
\text { cemas }(\%)\end{array}$ & $\begin{array}{c}\text { Sangat cemas } \\
\text { sekali }(\%)\end{array}$ \\
\hline Sehari sebelum pencabutan gigi & 34,34 & 49,56 & 11,07 & 2,77 & 2,26 \\
Menunggu di ruang tunggu & 33,33 & 46,16 & 15,35 & 4,03 & 1,13 \\
Akan dibius lokal & 25,16 & 42,52 & 22,14 & 7,29 & 2,89 \\
Akan dilakukan pencabutan gigi & 17,86 & 41,26 & 23,77 & 11,95 & 5,16 \\
Akan dilakukan penjahitan bekas pencabutan & 11,45 & 27,55 & 32,45 & 15,59 & 12,96 \\
\hline
\end{tabular}

Tabel 9. Karakteristik persentase kecemasan saat pencabutan gigi kelompok usia 41-65 tahun

\begin{tabular}{lccccc}
\hline \multicolumn{1}{c}{ Aktivitas } & $\begin{array}{c}\text { Tidak } \\
\text { cemas }(\%)\end{array}$ & $\begin{array}{c}\text { Sedikit } \\
\text { cemas }(\%)\end{array}$ & $\begin{array}{c}\text { Cemas } \\
(\%)\end{array}$ & $\begin{array}{c}\text { Sangat } \\
\text { cemas }(\%)\end{array}$ & $\begin{array}{c}\text { Sangat cemas } \\
\text { sekali }(\%)\end{array}$ \\
\hline Sehari sebelum pencabutan gigi & 46,99 & 42,17 & 7,23 & 3,61 & 0 \\
Menunggu di ruang tunggu & 45,78 & 44,58 & 6,02 & 3,61 & 0 \\
Akan dibius lokal & 36,14 & 38,55 & 16,78 & 7,23 & 1,20 \\
Akan dilakukan pencabutan gigi & 28,92 & 39,76 & 22,89 & 6,02 & 2,41 \\
Akan dilakukan penjahitan bekas pencabutan & 15,66 & 38,55 & 31,33 & 9,64 & 4,82 \\
\hline
\end{tabular}

Tabel 10. Karakteristik persentase kecemasan saat pencabutan gigi laki-laki dan perempuan

\begin{tabular}{|c|c|c|c|c|c|c|c|c|c|c|}
\hline \multirow[t]{2}{*}{ Aktivitas } & \multicolumn{2}{|c|}{ Tidak cemas } & \multicolumn{2}{|c|}{ Sedikit cemas } & \multicolumn{2}{|c|}{ Cemas } & \multicolumn{2}{|c|}{$\begin{array}{l}\text { Sangat } \\
\text { cemas }\end{array}$} & \multicolumn{2}{|c|}{$\begin{array}{l}\text { Sangat cemas } \\
\text { sekali }\end{array}$} \\
\hline & $\hat{0}$ & q & $\hat{0}$ & q & $\hat{o}$ & 9 & $\hat{0}$ & q & $\hat{\sigma}$ & P \\
\hline $\begin{array}{l}\text { Sehari sebelum pencabutan } \\
\text { gigi }\end{array}$ & 40,80 & 27,59 & 45,25 & 54,07 & 10,39 & 11,64 & 2,52 & 3,03 & 0,89 & 3,35 \\
\hline Menunggu di ruang tunggu & 40,06 & 28,71 & 42,88 & 47,37 & 12,31 & 16,59 & 3,56 & 4,94 & 1,04 & 2,07 \\
\hline Akan dibius lokal & 30,27 & 20,26 & 41,25 & 40,67 & 19,14 & 24,24 & 6,68 & 9,09 & 2,52 & 5,42 \\
\hline $\begin{array}{l}\text { Akan dilakukan pencabutan } \\
\text { gigi }\end{array}$ & 23,59 & 14,19 & 41,25 & 38,12 & 20,33 & 26,79 & 10,98 & 12,60 & 3,71 & 7,97 \\
\hline $\begin{array}{l}\text { Akan dilakukan penjahitan } \\
\text { bekas pencabutan }\end{array}$ & 14,99 & 6,22 & 28,34 & 25,84 & 31,75 & 26,95 & 13,50 & 19,94 & 11,28 & 20,73 \\
\hline
\end{tabular}

Tabel 11. Karakteristik persentase kecemasan saat pencabutan gigi pada masyarakat Indonesia bagian barat

\begin{tabular}{lccccc}
\hline \multicolumn{1}{c}{ Aktivitas } & $\begin{array}{c}\text { Tidak } \\
\text { cemas(\%) }\end{array}$ & $\begin{array}{c}\text { Sedikit } \\
\text { cemas(\%) }\end{array}$ & $\begin{array}{c}\text { Cemas } \\
(\%)\end{array}$ & $\begin{array}{c}\text { Sangat } \\
\text { cemas(\%) }\end{array}$ & $\begin{array}{c}\text { Sangat cemas } \\
\text { sekali(\%) }\end{array}$ \\
\hline Sehari sebelum pencabutan gigi & 33,98 & 49,17 & 11,57 & 3,15 & 1,85 \\
Menunggu di ruang tunggu & 34,35 & 45,19 & 14,35 & 4,17 & 1,67 \\
Akan dibius lokal & 25,19 & 40,46 & 22,13 & 8,24 & 3,70 \\
Akan dilakukan pencabutan gigi & 18,61 & 39,91 & 23,33 & 12,41 & 5,46 \\
Akan dilakukan penjahitan bekas & 11,39 & 26,85 & 28,33 & 16,76 & 16,48 \\
pencabutan & & & & & \\
\hline
\end{tabular}

Tabel 12. Karakteristik persentase kecemasan saat pencabutan gigi pada masyarakat Indonesia bagian tengah

\begin{tabular}{lccccc}
\hline \multicolumn{1}{c}{ Aktivitas } & $\begin{array}{c}\text { Tidak } \\
\text { cemas }(\%)\end{array}$ & $\begin{array}{c}\text { Sedikit } \\
\text { cemas }(\%)\end{array}$ & $\begin{array}{c}\text { Cemas } \\
(\%)\end{array}$ & $\begin{array}{c}\text { Sangat } \\
\text { cemas }(\%)\end{array}$ & $\begin{array}{c}\text { Sangat cemas } \\
\text { sekali }(\%)\end{array}$ \\
\hline Sehari sebelum pencabutan gigi & 40,69 & 51,03 & 4,83 & 0,69 & 2,76 \\
Menunggu di ruang tunggu & 42,07 & 38,62 & 15,17 & 3,45 & 0,69 \\
Akan dibius lokal & 27,59 & 44,14 & 18,62 & 5,52 & 4,14 \\
Akan dilakukan pencabutan gigi & 24,14 & 37,93 & 22,76 & 7,59 & 7,59 \\
Akan dilakukan penjahitan bekas & 8,97 & 30,34 & 33,10 & 15,17 & 12,41 \\
pencabutan & & & & & \\
\hline
\end{tabular}


Tabel 13. Karakteristik persentase kecemasan saat pencabutan gigi pada masyarakat Indonesia bagian timur

\begin{tabular}{lccccc}
\hline \multicolumn{1}{c}{ Aktivitas } & $\begin{array}{c}\text { Tidak } \\
\text { cemas }(\%)\end{array}$ & $\begin{array}{c}\text { Sedikit } \\
\text { cemas }(\%)\end{array}$ & $\begin{array}{c}\text { Cemas } \\
(\%)\end{array}$ & $\begin{array}{c}\text { Sangat } \\
\text { cemas(\%) }\end{array}$ & $\begin{array}{c}\text { Sangat cemas } \\
\text { sekali(\%) }\end{array}$ \\
\hline Sehari sebelum pencabutan gigi & 28,95 & 51,32 & 14,47 & 1,32 & 3,95 \\
Menunggu di ruang tunggu & 23,68 & 55,26 & 13,16 & 6,58 & 1,32 \\
Akan dibius lokal & 25 & 42,11 & 19,74 & 6,58 & 6,58 \\
Akan dilakukan pencabutan gigi & 15,79 & 40,79 & 26,32 & 10,53 & 6,58 \\
Akan dilakukan penjahitan bekas & 6,58 & 25 & 38,16 & 17,11 & 13,16 \\
pencabutan & & & & \\
\hline
\end{tabular}

\section{PEMBAHASAN}

Secara keseluruhan, responden memiliki rasa cemas yang ringan atau tidak cemas $(46,22 \%)$, diikuti cemas sedang $(41,83 \%)$ kemudian cemas tinggi $(7,32 \%)$ dan cemas parah (fobia) $(4,62 \%)$ (Tabel 4). Hal ini sesuai dengan hasil penelitian Rahmayani di RSGMP USU tahun 2014 yang menunjukkan responden berada pada kategori cemas ringan $89,4 \%{ }^{8}$ Berdasarkan kategori usia, responden usia pubertas (11-20 tahun) kategori cemas sedang 43,51\% sedangkan usia dewasa (21-40 tahun) dan usia setengah umur (41-65 tahun) cenderung memiliki kecemasan rendah atau tidak cemas $47,04 \%$ dan $62,65 \%$. Hal yang sama juga terlihat dari penelitian Bushra dkk. di Pakistan pada tahun 2010 yang menunjukkan penurunan tingkat kecemasan seiring bertambahnya umur yaitu 18-33 tahun 94\%, 34-49 tahun 86\% dan diatas 50 tahun $80 \% .{ }^{17}$ Penjelasan mengenai hubungan ansietas dental berkurang seiring bertambahnya usia karena kemampuan seseorang dalam menerima pengalaman dan belajar dari pengalaman tersebut serta semakin dewasa seseorang, sehingga kemampuan seseorang dalam merasionalkan pengalaman semakin tinggi. ${ }^{17,18}$

Perempuan kategori cemas sedang 45,44\% sedangkan laki-laki kategori tidak cemas atau cemas rendah 52,75\%. Hal ini sesuai dengan penelitian AlOmari dan Al-Omiri pada tahun 2008 dan penelitian CM Marya dkk. pada tahun 2012 yaitu perempuan mempunyai tingkat kecemasan yang lebih tinggi daripada pria. Hal ini dikarenakan wanita memiliki tingkat toleransi terhadap rasa sakit yang lebih rendah karena wanita mempunyai tingkat neurosis (kecenderungan mengalami keadaan emosional negatif) yang lebih tinggi dibandingkan pria. Kecemasan berhubungan dengan tingkat neurosis, laki-laki juga memiliki emosional yang lebih stabil daripada wanita dan wanita lebih mengakui merasa cemas. ${ }^{18-20}$

Berdasarkan asal daerah, penelitian ini merupakan penelitian yang pertama kali membandingkan antara ketiga wilayah di Indonesia. Hasil penelitian menunjukkan bahwa masyarakat yang tinggal di bagian barat dan tengah Indonesia termasuk kategori tidak cemas atau cemas ringan $(46,05 \%$ dan $52,41 \%)$.
Namun, masyarakat yang tinggal di bagian timur Indonesia termasuk kategori cemas sedang (52,63\%). Perbedaan dari ketiga wilayah tersebut masih kurang jelas namun beberapa penjelasan yang mungkin terjadi adalah kecemasan dental memiliki penyebab yang multifaktorial misalnya pengalaman traumatik atau pengalaman yang tidak menyenangkan baik yang dialami oleh responden maupun yang dilihat oleh responden. ${ }^{21}$

Kelompok usia 11-20 tahun dan kelompok usia 21-40 tahun tampak sedikit cemas ketika sehari sebelum pencabutan gigi dan ketika menunggu di ruang tunggu, namun kelompok usia 41-65 tahun memiliki kecenderungan tidak merasa cemas. Persentase yang sama $(23,80 \%)$ tampak pada kelompok usia 11-20 tahun antara responden yang merasa sedikit cemas dan responden yang cemas ketika bekas pencabutan akan dijahit, sedangkan pada kelompok usia 21-40 tahun dominan merasa cemas $(32,45 \%)$ dan kelompok usia 41-65 tahun dominan merasa sedikit cemas (36,55\%). Hal ini sedikit berbeda dengan penelitian Al-Omari dan Al-Omiri serta Adelina Rahmayani dikarenakan pe-nelitian ini menggunakan Modified Dental Anxiety Scale yang dimodifikasi sehingga terlihat pergantian pertanyaan menjadi tingkat kecemasan responden ketika akan dilakukan penjahitan bekas pencabutan gigi.

Kecemasan responden juga terlihat berubah dari sedikit cemas menjadi cemas baik pada kelompok umur, jenis kelamin dan asal daerah, kecuali untuk masyarakat Indonesia bagian timur ketika responden akan dibius lokal. Hal yang sama terlihat dari penelitian LF Joyce Kandou yang menyatakan bahwa distribusi tingkat kecemasan subjek penelitian meningkat setelah dianestesi dibandingkan ketika sebelum dianestesi. Hasil pada kategori kecemasan sedang sebelum dianestesi dikarenakan pengaruh ruangan, operator dan kemungkinan melihat alat kedokteran gigi yang menghasilkan kategori kecemasan yang lebih rendah daripada kelompok sesudah dianestesi. Rasa cemas menjadi lebih tinggi ketika jarum suntik masuk ke mukosa yang akan menyebabkan rasa sakit. Rasa sakit dan tidak nyaman tersebut memicu sistem saraf simpatis untuk menghadapi bahaya dan memicu kecemasan subjek pe- 
nelitian sehingga angka kecemasan pasien me-ningkat. $^{9}$

Keterbatasan penelitian ini adalah kemungkinan data yang diperoleh tidak objektif dikarenakan data berasal dari responden tanpa bertatap muka langsung (melalui dunia maya) sehingga tidak tertutup kemungkinan responden memberikan data yang salah.

\section{Daftar Pustaka}

1. Hmud R, Waish LJ. Dental anxiety: Causes, complications and management approaches. J Minim Interv Dent 2009; 2(1): 67-78.

2. WebMD. Anxiety \& panic disorders health center. $<$ http://www.webmd.com/anxietypanic/guide/menta 1-health-anxiety-disorders $>$. (30 Agustus 2014).

3. American Psychology Association. Anxiety. $<$ http:/ /www.apa.org/topics/anxiety>.(30 Agustus 2014).

4. The Editors of Encyclopaedia Britannica. Anxiety. 9 Maret 2014. <http://www.britannica.com/ EBchecked/topic/29092/anxiety>. (30 Agustus 2014).

5. Hollander J. An assessment of dental fear and anxiety: comparing doctor and patient perceptions. Oral Health Journal 2007; 97(12): 9-14.

6. Armfield J. The avoidance and delaying of dental visits in Australia. Australian Dent J 2012; 57: 4.

7. Appukuttan D, Datchnamurthy M, Deborah SP, Hirudayaraj GJ, et al. Reliability and validity of the Tamil version of Modified Dental Anxiety Scale. J of Oral Science 2012; 54(4): 313-20.

8. Rahmayani A. Perbedaan tingkat kecemasan dental pasien pria dan wanita sebelum pencabutan gigi di departemen bedah mulut RSGMP FKG USU Medan. Skripsi. Medan: Universitas Sumatera Utara, Fakultas Kedokteran Gigi; 2014.

9. Mawa MAC, Kandou LFJ, Anindita PS. Gambaran tingkat kecemasan pasien usia dewasa pra tindakan pencabutan gigi di Balai Pengobatan Rumah Sakit Gigi dan Mulut Manado. eG 2013; 1(2).

10. The Jakarta Post. Number of RI internet users increases to 71.19 million in 2013: APJII. 15 Januari 2014.<http://www.thejakartapost.com/news/2014/0 1/15/number-ri-internet-users-increases-7119-million-2013-apjii.html>. (30 Agustus 2014).

11. The Jakarta Post. RI highly dependent on mobile internet. 12 Juli 2011. <http://www.thejakartapost. com/news/2011/07/12/rihighly-dependent-mobileinternet.html>. (30 Agustus 2014).

12. The Central Intelligence Agency. The World Factbook. 22 Juni 2014. <https://www.cia.gov/ library/ publications/the-world-factbook/geos/id.html >. (23 Oktober 2014).

13. GMT. Indonesia Time. 2 Agustus 2013. <http:// wwp.greenwichmeantime.com/time-zone/asia/indonesia/time-indonesia/>. (23 Oktober 2014).

14. Indonesian Embassy. Embassy of the Republic of Indonesia. <http://www.indonesianembassy.org. uk/ aboutIndonesia/indonesia_facts.html $>$. (23 Oktober 2014).

15. Ferry E, Makhfudli. Keperawatan kesehatan komunitas: Teori dan praktik dalam keperawatan. Jakarta: Salemba Medika, 2009: 243.

16. Freeman R, Clarke HM, Humphris GM. Conversion tables for the Corah and modified dental anxiety scales. Community Dent Health 2007 Mar; 24(1): 49-54.

17. Mehboob B, Khan E, Khan M. Dental anxiety scale in exodontia patients. JKCD 2011; 1: 67-8.

18. Marya CM, Grover S, Jnaneshwan A, et al. Dental anxiety among patients visiting a dental institute in Faridadad, India. West India Med J 2012; 61:188-9.

19. Al-Omari WM, Al-Omiri MK. Dental anxiety among university students and its correlation with their field of study. J Appl Oral Sci 2009; 17(3): 202.

20. Malvania EA, CG Ajithkrishnan. Prevalence and socio-demographic correlates of dental anxiety among a group of adult patients attending a dental institution in Vadodara City, Gujarat, India. Indian. J Dent Res 2011; 22(1): 179-80.

21. Oktay EA, Kocak MM, Sahinkesen G, Topcu FT. The role of age, gender, education, and experiences on dental anxiety. Gulhane Med J 2009; 51(3): 145-8. 